\title{
To Study the Difference in the Participation Level of Parents in the Education of Pakistani Students from Grade 7 To 10: Relation with Gender and Level of Studies
}

\author{
Dr. Zeenat Ismail \\ Professor \\ Department of Social Sciences \& Liberal Arts \\ Institute of Business Administration - Karachi
}

\begin{abstract}
This study examined the relationship between parental involvement and academic performance of students from grade 7 to 10 . The sample consisted of 100 literate parents who were at least high school graduates (Inter or A levels), 50 mothers and 50 fathers who were randomly selected. Before conducting the research, two things were hypothesized. Firstly, parental involvement promotes students academic success and secondly mothers tend to be more involved than fathers. Correlation was used to examine the relationship between parental involvement and academic performance. The results showed that there was a strong positive correlation of .751 between parental involvement and academic performance. Regression analysis was used to determine how strong the relationship between parental involvement and academic performance was and significance level was found out to be less than 0.05 showing significant relationship. Independent $t$ test was used to evaluate the difference between the participation of mothers and fathers and the results showed a significant level of 0.01 which was less than 0.05 showing significant variation in the participation of mothers and fathers with mothers participation was greater than the fathers. For both the hypotheses, null hypothesis was rejected and alternate hypothesis was accepted.
\end{abstract}

Keywords: Parents, Education, Participation, Pakistan, Parent involvement, Academic achievement.

\section{INTRODUCTION}

Parents are a source of motivation and support that a child needs when he or she is growing up. Parents act as a backbone for children because they help children to sustain their lives. As children get old parents tend to slightly disintegrate with their child thinking that their child needs independence or that their child would not like their interference anymore. Adolescence is an extremely important age in an individual' life because physical, cognitive and socio emotional development is taking place during this time period. This is why adolescence needs parents to be by their side in this critical period and contrary to the mainstream perception, in this study I will look at how parental involvement has a strong influence on academic performance of children.

This research is focused on the quality of education of children which involves a shared responsibility by both the parents and teachers to create better conditions to promote student's academic success. It highlights the importance of developing family-school relationships to improve the quality of education. Parental involvement basically refers to interdependent lives of parents and adolescence and both are viewed as trajectories that are intricately related to the curricular location of the student. For example academically oriented students are already on higher tracks while parental involvement can steer some adolescents 
into higher tracks. Over time, parents become less involved in their child's educational careers especially after elementary schools because students start desiring autonomy and parents try to give more space to the adolescents.

Adolescence is a very crucial stage in an individual's life. This is the stage when the individual is seeking their identity and seeking for independence. Therefore, parental involvement is extremely important during this stage. Parental involvement is considered to have a positive relationship with academic success. Students whose parents' participate keep a track of their child's academic records and help the child in times of need will lead to the child performing well, have a higher social esteem and the child is also much likely to be a successful individual. Involvement allows parents to monitor school in classroom activities and also to coordinate with the teachers to ensure that the child is progressing well. Teachers of students whose parents are highly involved tend to give greater attention to students as well because it gives encouragement to teachers as well. Interactive assignments are also quite valuable because they bring parents and children close together.

There are various factors that influence parental involvement. When a child reaches high school, parents do not find it necessary to keep a check on the academic performance of the child because they feel that the child has become independent enough to keep a balance in his studies. However, there are some parents who are more willing to participate but they face certain obstacles that create a hindrance in their involvement. Certain factors that can influence parental involvement may include Parents of more successful students are likely to disengage because they feel less need to monitor their progress and have less motivation to engage in their activities as compared to students who aren't doing so well in school. Their parents are more likely to be involved. Certain social factors also has an influence on parental involvement such as intact families, parental education and socioeconomic status tend to predict greater involvement.

\section{LITERATURE REVIEW}

Various researches have been done on this topic in the past years relating to the factors that may contribute to less or more parental involvement. The terms "Parental involvement" or "Parental participation" are nebulous because they can include an array of parental behaviors. This term can mean different things to different people. A two way break down has been made to define parental involvement. One is home based activities such as parent home tutoring and the other is school based parental involvement activities such as parent volunteering or attendance of parents in parent-teacher conferences. Parental involvement basically refers to interdependent lives of parents and adolescence and both are viewed as trajectories that are intricately related to the curricular location of the student. In the study by Chen2, X. F. (2001) argues that we view parental involvement simplistically and it is often perceived as a onedimensional reality but we should take a multifaceted approach because parental involvement includes a variety of behavioral patterns and parenting practices. Moreover, certain aspects of parental involvement may have greater effects compared to others. There are various indicators to measure academic achievement which can range from global indicators such as GPA which is widely used in colleges across the globe and there are certain specific academic areas such as math to measure achievement. It is very likely that the degree of parental involvement might vary depending on the academic achievement measure.

\section{PROBLEM STATEMENT}

The purpose of this research study is to examine the relationship between parental involvement and academic performance of high school students. This study will look at the 
factors that contribute to parental involvement and how does that influence the academic achievement.

\section{Rationale}

Parental involvement is a key factor that has a huge impact on the development of the child. Various researches have been conducted on parental involvement but this research will be conducted on Pakistani parents in order to evaluate the importance of parental involvement and its likely benefits on academic performance. This research will seek to provide information to parents about the possible benefits of parental involvement and whether or not parental involvement leads to a positive impact on academic performance of the student.

\section{Hypotheses}

\section{Hypotheses 1:}

Independent variable: parental involvement

Dependant variable: academic performance.

H1: Participation by parents promotes student's academic success.

H0: Participation by parents does not promote student's academic success.

\section{Hypotheses 2:}

Independent variable: involvement of mothers.

Dependant variable: academic performance.

H1: Mothers are more involved in the activities of the students as compared to fathers.

HO: there is no difference in the involvement of mothers and fathers.

\section{METHODOLOGY}

This study will include a questionnaire that will be based on Epstein (2011) model which involves six critical dimensions that are used to evaluate the participation of parents:

This is the scale I will use to measure parental involvement:

1) Parenting: (e.g. "I make positive comments regarding my child's behavior")

2) Communication with the school: (e.g. "I talk with teachers and other school personnel about my child are learning.

3) Support learning at home: (e.g. I provide proper resources to my child to perform his work.)

4) Volunteering: (e.g. I participate as a speaker at conferences and workshops for children.

5) Decision making: (e.g. I vote in the elections for members of the parent's associations.

6) Collaboration with the community: (e.g. I participate in activities where students can learn by serving the community.)

\section{Sample size}

100 literate parents who are at least high school graduates (Inter or A levels). The students would be ranging from grade 7 to 10 . 
The questionnaire included a 5 point Likert scale that ranges from 1 (strongly disagree) to 5 (strongly agree)

\section{Statistics}

Statistics I will use for this research would be correlation, regression and independent sample $t$ test. Correlation would examine the whether there is a relationship between parental involvement and academic performance and regression will help determine how strong the relationship between these two independent variables are and also whether there is a causal relationship between the two. Independent t test was used to compare parental involvement between males and females.

\section{ARKANSAS SCORING CRITERIA- ACADEMIC PERFORMANCE SCALE}

PERFORMANCE - The student's demonstration of skill while attempting a given task. Each individual task (portfolio entry) is scored for Performance. LEVEL OF ASSISTANCE Determined after the introduction of the lesson activity. The observed accommodations, adaptations, and/or assistance provided to a student during performance of tasks. Each individual task (portfolio entry) is scored for Level of Assistance.

\begin{tabular}{|c|c|c|c|c|}
\hline $\begin{array}{l}\text { DOMAIN* see } \\
\text { definitions below }\end{array}$ & Score 1 & Score 2 & Score 3 & Score 4 \\
\hline PERFORMANCE & $\begin{array}{l}\text { Student does not } \\
\text { perform the task } \\
\text { with any } \\
\text { evidence of skill }\end{array}$ & $\begin{array}{l}\text { Student } \\
\text { attempts the } \\
\text { task, but there is } \\
\text { only minimal } \\
\text { evidence of skill }\end{array}$ & $\begin{array}{l}\text { Student performs } \\
\text { the task with } \\
\text { reasonable skill }\end{array}$ & $\begin{array}{l}\text { Student performs } \\
\text { the task with } \\
\text { mastery as } \\
\text { demonstrated in } \\
\text { multiple settings } \\
\text { or on multiple } \\
\text { occasions }\end{array}$ \\
\hline $\begin{array}{l}\text { DOMAIN* see } \\
\text { definitions below }\end{array}$ & Score 1 & Score 2 & Score 3 & Score 4 \\
\hline LEVEL OF ASSISTANCE & $\begin{array}{l}\text { Following the } \\
\text { introduction of } \\
\text { the lesson or } \\
\text { activity, student } \\
\text { performs only } \\
\text { with maximum } \\
\text { physical } \\
\text { assistance (such } \\
\text { as hand-over- } \\
\text { hand support) }\end{array}$ & $\begin{array}{l}\text { Following the } \\
\text { introduction of } \\
\text { the lesson or } \\
\text { activity, student } \\
\text { performs with } \\
\text { direct verbal } \\
\text { prompting, } \\
\text { modeling, } \\
\text { gesturing or } \\
\text { some physical } \\
\text { support }\end{array}$ & $\begin{array}{l}\text { Following the } \\
\text { introduction of the } \\
\text { lesson or activity, } \\
\text { student performs } \\
\text { in response to } \\
\text { teacher-planned } \\
\text { instructional/ } \\
\text { social } \\
\text { supports (e.g., } \\
\text { peers, technology, } \\
\text { materials } \\
\text { supports) }\end{array}$ & $\begin{array}{l}\text { Following the } \\
\text { introduction of the } \\
\text { lesson or activity, } \\
\text { student performs } \\
\text { independently OR } \\
\text { student initiates } \\
\text { the activity with } \\
\text { the use of natural } \\
\text { environmental or } \\
\text { social supports }\end{array}$ \\
\hline
\end{tabular}




\section{RESULTS}

The results were calculated using Correlation, Regression and Independent sample t test.

\section{Correlations:}

\begin{tabular}{|ll|r|r|}
\multicolumn{2}{c|}{ Correlations } \\
\hline \multirow{2}{*}{ Total_Parental_invol } & Pearson Correlation & T_P_involvement & T_acad_perf \\
vement & Sig. (2-tailed) & 1 & $.751^{* *}$ \\
& $\mathrm{~N}$ & 102 & .000 \\
& Pearson Correlation & $.751^{* *}$ & 101 \\
T_academic_perform & Sig. (2-tailed) & .000 & 1 \\
ance & $\mathrm{N}$ & 101 & 106 \\
\end{tabular}

**. Correlation is significant at the 0.01 level (2-tailed).

Coefficients $^{\mathrm{a}}$

\begin{tabular}{|c|c|c|c|c|c|c|c|c|c|c|c|c|}
\hline \multirow[t]{2}{*}{ Model } & \multicolumn{2}{|c|}{$\begin{array}{l}\text { Unstandardize } \\
\text { d Coefficients }\end{array}$} & \multirow{2}{*}{$\begin{array}{c}\begin{array}{c}\text { Standardize } \\
\mathrm{d} \\
\text { Coefficients }\end{array} \\
\text { Beta }\end{array}$} & \multirow[t]{2}{*}{$\mathrm{t}$} & \multirow[t]{2}{*}{ Sig. } & \multicolumn{2}{|c|}{$\begin{array}{c}95.0 \% \\
\text { Confidence } \\
\text { Interval for B }\end{array}$} & \multicolumn{3}{|c|}{ Correlations } & \multicolumn{2}{|c|}{$\begin{array}{l}\text { Collinearity } \\
\text { Statistics }\end{array}$} \\
\hline & B & $\begin{array}{l}\text { Std. } \\
\text { Error }\end{array}$ & & & & $\begin{array}{l}\text { Lower } \\
\text { Bound }\end{array}$ & $\begin{array}{l}\text { Upper } \\
\text { Bound }\end{array}$ & $\begin{array}{l}\text { Zero- } \\
\text { orde } \\
r\end{array}$ & $\begin{array}{c}\text { Partia } \\
\quad 1\end{array}$ & Part & $\begin{array}{c}\text { Toleranc } \\
\mathrm{e}\end{array}$ & VIF \\
\hline $1^{\text {(Constant) }}$ & -4.208 & 2.949 & & -1.427 & .157 & $\begin{array}{r}- \\
10.05 \\
9\end{array}$ & 1.642 & & & & & \\
\hline T_P_involvement & .274 & .024 & .751 & $\begin{array}{r}11.33 \\
1\end{array}$ & .000 & .226 & .322 & .751 & .751 & .751 & 1.000 & $\begin{array}{r}1.00 \\
0\end{array}$ \\
\hline
\end{tabular}

\section{a. Dependent Variable: T_acad_perf}

The relationship between parental involvement and academic performance was calculated using Pearson correlation coefficient. There was strong positive correlation between the two variables $[\mathrm{r}=-.751 \mathrm{n}=101, \mathrm{p}<.05]$

\section{Regression:}

$\mathbf{S}$

\begin{tabular}{|l|r|r|r|c|}
\hline Model & \multicolumn{1}{|c|}{$\mathrm{R}$} & R Square & \multicolumn{1}{c|}{$\begin{array}{c}\text { Adjusted R } \\
\text { Square }\end{array}$} & $\begin{array}{c}\text { Std. Error of the } \\
\text { Estimate }\end{array}$ \\
\hline 1 & $.756^{\mathrm{a}}$ & .571 & .567 & 3.25143 \\
\hline
\end{tabular}

a. Predictors: (Constant), T_P_involvement

b. Dependent Variable: T_acad_perf

ANOVA $^{\mathrm{a}}$

\begin{tabular}{|rl|r|r|r|r|r|}
\hline Model & & Sum of Squares & df & Mean Square & F & Sig. \\
\hline \multirow{3}{*}{1} & Regression & 1361.604 & 1 & 1361.604 & 128.401 & $.000^{\mathrm{b}}$ \\
& Residual & 1049.825 & 99 & 10.604 & & \\
& Total & 2411.429 & 100 & & & \\
\hline
\end{tabular}

a. Dependent Variable: T_acad_perf b. Predictors: (Constant), T_P_involvment

Multiple linear regression analysis was used to develop a model for predicting influences of parental involvement and academic performance of their child. The two predictors account for $57.1 \%$ of the variance academic performance, $\mathrm{F}=128.401, \mathrm{p}<.05, \mathrm{R}^{2}=.571$ Both predictors were showing statistically significant predictive beta coefficients. 


\section{Histogram:}

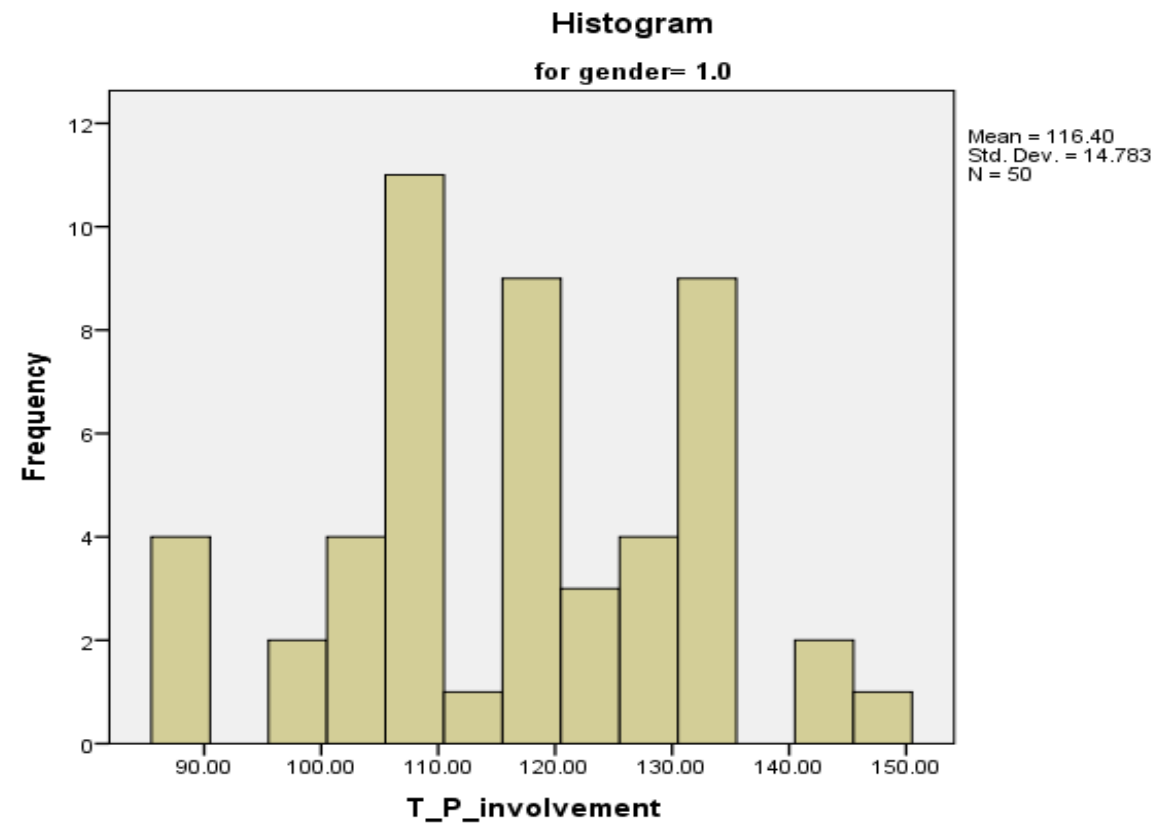

In the histogram, gender 1.0 represents males and gender 2.0 represents females. We can see that the histogram foe males have a lower frequency of around 11 as compared to the frequency of females of more than 12.5. For both males and females the data seems to be normally distributed but males have more variations as compared to females showing greater parental involvement in females.

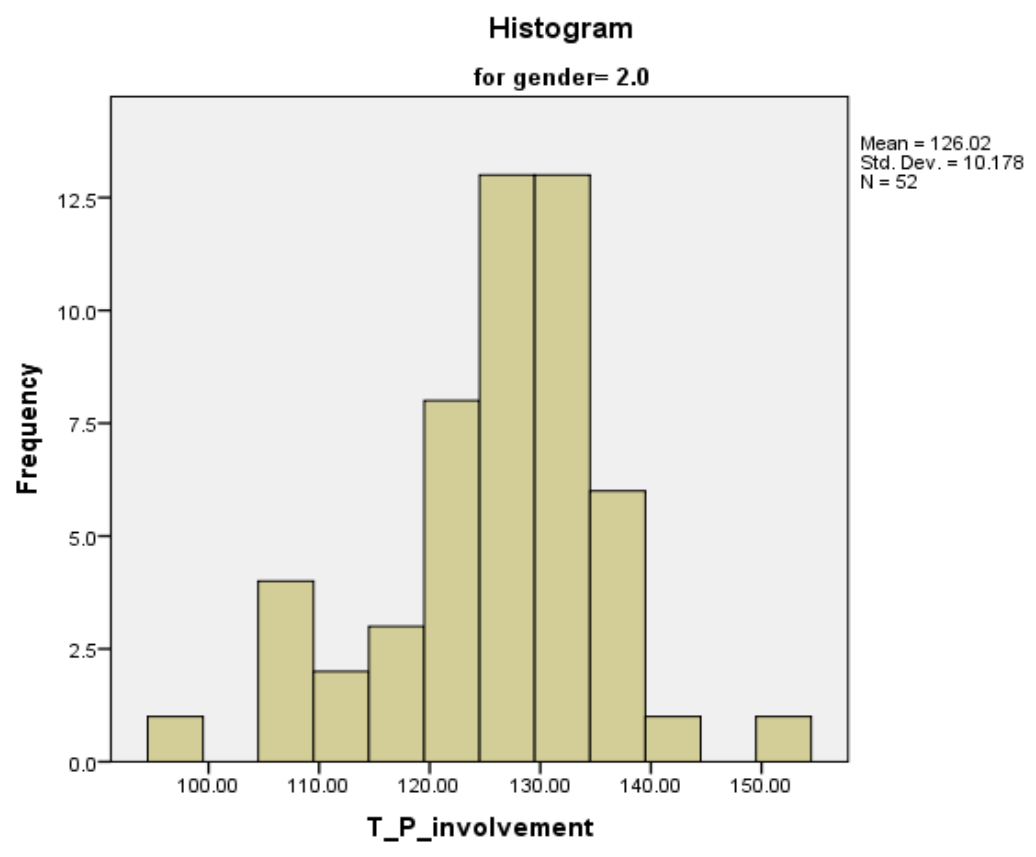


Independent T Test:

\begin{tabular}{|r|l|r|r|r|r|}
\hline & gender & N & Mean & Std. Deviation & Std. Error Mean \\
\hline \multirow{2}{*}{ T_P_involvement } & 1.0 & 50 & 116.9000 & 15.11892 & 2.13814 \\
& 2.0 & 52 & 126.0192 & 10.17781 & 1.41141 \\
\hline
\end{tabular}

Independent Samples Test

\begin{tabular}{|c|c|c|c|c|c|c|c|c|c|c|}
\hline & \multicolumn{2}{|c|}{$\begin{array}{c}\text { Levene's Test for } \\
\text { Equality of } \\
\text { Variances }\end{array}$} & \multicolumn{7}{|c|}{ t-test for Equality of Means } \\
\hline & & \multirow[t]{2}{*}{$F$} & \multirow[t]{2}{*}{ Sig. } & \multirow[t]{2}{*}{$\mathrm{t}$} & \multirow[t]{2}{*}{ df } & \multirow{2}{*}{$\begin{array}{l}\text { Sig. } \\
(2- \\
\text { tailed })\end{array}$} & \multirow[t]{2}{*}{$\begin{array}{c}\text { Mean } \\
\text { Difference }\end{array}$} & \multirow[t]{2}{*}{$\begin{array}{l}\text { Std. Error } \\
\text { Difference }\end{array}$} & \multicolumn{2}{|c|}{$\begin{array}{l}95 \% \text { Confidence Interval of the } \\
\text { Difference }\end{array}$} \\
\hline & & & & & & & & & Lower & Upper \\
\hline \multirow{2}{*}{$\begin{array}{l}\mathrm{T}_{-} \mathrm{P}_{-} \\
\text {involvement }\end{array}$} & $\begin{array}{l}\text { Equal variances } \\
\text { assumed }\end{array}$ & 12.840 & .001 & 3.586 & 100 & .001 & -9.11923 & 2.54295 & $14.16437^{-}$ & -4.07409 \\
\hline & $\begin{array}{l}\text { Equal variances } \\
\text { not assumed }\end{array}$ & & & 3.559 & 85.423 & .001 & -9.11923 & 2.56197 & $14.21276^{-}$ & -4.02571 \\
\hline
\end{tabular}

An independent-sample t-test was conducted to compare the parental involvement scores for males and females. There was significant difference in scores for males $(M=116.9, S D=15.1 \mathrm{t}$ (3.586) and females [M=126.01 $S D=10.1 ; t(3.559), p=.001]$.(eta square= 0.11) Since the significance level is .001 , we can conclude that there was significant difference in parental involvement between males and female where females had greater parental involvement than males. The eta square is 0.11 showing a large effect.

\section{DISCUSSION}

After conducting the research to examine the impact of parental involvement on academic performance, the results demonstrated a strong, positive correlation of .765 between parental involvement and academic performance of their child. Therefore, parents who tend to be more involved in the education of their children can have a positive impact on academic performance. Moreover, results also showed that there were significant differences between the involvement in males and females. Conclusions were also drawn Through eta square of 0.11 symbolizing a large variation in the participation of mothers and fathers. Mothers were more involved in the education of children. In addition, the histogram showed that females' involvement was more normally distributed as compared to males who had greater variations in their involvement. Hence, after evaluating the results, conclusions can be drawn about the hypotheses that were proposed at the beginning of the research. The null hypothesis (H0), that participation by parents does not promote students academic success was rejected and the alternate hypothesis (H1), that parents promotes students academic success was accepted. For the second hypothesis, the null hypothesis (HO) that there was no difference in the participation of mothers and fathers was rejected and the alternate hypothesis (H1), mothers tend to be more involved than fathers was accepted. After conducting an independent sample $t$ test, results showed that there was significant difference in the parental involvement between mothers and fathers and mothers were more involved than fathers. The results also support the views of many studies that were conducted in the literature review which considered parental involvement as a very significant tool for a better academic performance of children as it leads to greater progress for the child. However, we cannot generalize the results through this research because the sample size used in this research was very small and there was a great tendency that parents might not provide an accurate representation of the academic performance of their child. likewise, we can also not make generalizations through this research because there are various other factors that can contribute to parental involvement as well as academic performance. 


\section{Managerial Implications}

This research can have several practical usages. Firstly, it can provide knowledge about the benefits of parental involvement so that more parents become engaged in their children's education. Secondly, it will also encourage fathers to take an active role in the education of their children as parents act as a strong support and a great source of motivation for their children. This research is also significant because it will make parents realize of the importance of parental involvement as their children grow older. Giving Independence to children is not as necessary for adolescence as much as the support and motivation by parents can help.

\section{Limitations of the research}

One of the biggest limitations of the research was that the sample size was very small. Only 100 parents were included and therefore we cannot make any generalizations from the results. Secondly, there were some outliers in the research for example there were certain questionnaires that were filled by parents who did not belong to the category of grades that I was looking at. Comparison between mothers and fathers was also spurious because mothers and fathers who participated in the research were not parents of the same child.

\section{Recommendations for future researches}

Future researches on the effect of parental involvement on academic performance of children can focus on taking a more accurate scale to measure academic performance. Parents generally tend to be bias towards their children so when asking questions on academic performance of their children; they are more likely to present their child in the best possible way. This means that they might have portrayed an inaccurate picture of the child. For example it is possible that parents say that there child poses a great academic performance which in reality might not be true. Therefore, if future researches can take the report cards of children to measure the academic performance, it is more likely to provide a realistic image of the academic performance. Secondly, future researches can also do a gender comparison for example looking at the impact of parental involvement on both girls and boys. In this research I did a comparison of fathers and mothers but they were not necessarily the parents of the same child. So, future researches can take parents of the same child as it will make the comparison between fathers and mothers more accurate and provide a more reasonable measure of parental involvement.

\section{CONCLUSION}

Research findings have shown that parental involvement is positively associated with academic performance. This shows parental involvement has a significant Impact on education of a child. Parents provide the motivation and support that children needs to do well in school. Moreover, research findings also show that mothers tend to be more involved than fathers because there is a general perception that mothers are more available for their children as compared to fathers because fathers find it difficult to manage between the home and the workplace. However, there is a slow change in trend and we can now see that both mothers and fathers are now more involved in the education of their children and the home itself. After conducting this research, conclusions about the crucial significance of parental involvement can be made.

\section{BIBLIOGRAPHY}

Alldred, R. E. (2000, Sep). A Typology of Parental Involvement in Education Centring on Children and Young People: Negotiating Familialisation, Institutionalisation and Individualisation . British Journal of Sociology of EducationVol. 21, No. 3, pp. 435-455 
Catherine, W (Dec., 1995 - Jan., 1996). The Future of High School Success: The Importance of Parent Involvement Programs, , Essays on the Future of Secondary Education. The High School Journal, Vol. 79, No. 2 ,pp. $125-128$.

Catsabis, S. (2001), Expanding knowledge of parental involvement in children's secondary education: connections with high school seniors' academic success. Social Psychology of Education 5 , pp. 149-177,

Chen2, X. F. (2001), Parental Involvement and Students' Academic. Educational Psychology Review, Vol. 13, No. 1, , pp 1-20.

Claire L. Pelton, B. L. (1986). Teacher perceptions of praent school communication- A collaborative analysis . Teacher Education Quarterly, Vol. 13, No. 2, Partnerships in Teacher Education , pp 67-83.

Conger, A. L. (Spring, 1984),. Differential Mother and Father Influences on the Educational Attainment of Black and White Women. The Sociological Quarterly, Vol. 25, No. 2 , pp. 239-250.

Crosnoe, R. (2001, October/November). Parental involvement in education, the influence of school.

Cunningham, A. J.-T. (2010). Planning Ahead: The Relationship Among School Support, Parental Involvement, and Future Academic Expectations in African American Adolescents. The Journal of Negro Education, Vol. 79, No. 2 , pp 137-150

Epstein, J. L. (1982). Teachers' reported practices of parent involvement: Problems and possibilities. . Elementary School Journal, 83 , pp. 103-113.

Epstein, J. L. (Jan, 1986). Parents' Reactions to Teacher Practices of Parent Involvement . The Elementary School Journal, Vol. 86, No. 3, pp. 277-294.

Eva M. Pomerantz, E. A. (2007, Sep). The How, Whom, and Why of Parents' Involvement in Children's Academic Lives: More Is Not Always Better . Review of Educational Research, Vol. 77, No. 3 , pp. 373-410.

Gonzalez, A. R. (2005, June). Parental Involvement-It's Contribution to High School Students Motivation. Educational Psychology Review, Vol. 17

Grossman, B. J. (1998). Counseling Parents of Senior High School Students . The Journal of Education, Vol. 154, No. 1 , pp.60-64.

Hasley, P. A. (2005). Parent Involvement in Junior High Schools: , A Failure to Communicate. American Secondary Education, Vol. 34, No. 1, pp. 57-69.

Heather T. Rowan-Kenyon, A. D. (2008, Sep. - Oct) Contextual Influences on Parental Involvement in College Going: Variations by Socioeconomic Class. The Journal of Higher Education, Vol. 79, No. 5 , pp. 564-586.

Hickman, C. W. (1995) High school parent involvement: Relationships with achievement, grade level, SES, and gender. Journal of Research and Development in Education, 28, , pp. 125-134.

Holmes, M. (1998). Do Parents Matter? Curriculum Inquiry, Vol. 28, No. 1 , pp 113-122.

Jennifer DePlanty, R. C.-K. ( (Jul. - Aug., 2007), Perceptions of Parent Involvement in Academic Achievement . The Journal of Educational Research, Vol. 100, No. 6 , pp. 361-368.

J.L\& Becker, H. (1982), Teachers' reported practices of parent involvement: Problems and possibilities. Elementary school journal,83, pp. 103-113.

Katerina Antonopoulou, K. K. (2011) Parental involvement in secondary education schools: the views of parents in Greece . Educational Studies , pp. 333-344.

Lemmons, I. A. (2013, Feb), Social Demographics, the School Environment, and Parenting Practices Associated with Parents' Participation in Schools and Academic Success among Black, Hispanic, and White Students. Journal of Human Behavior, pp. 237-255.

Ramirez, A. (2000), High School Teachers' View of Parent Involvement . American Secondary Education, Vol. 28, No. 4 , pp 27-32.

Ritter, S. M. (1988), Parents of High School Students: A Neglected Resource . Educational Horizons, Vol. 66, No. 2, PARENTS and SCHOOLS, pp 75-77.

Sayer, L. C. (n.d.), Are Parents Investing Less in Children? Trends in Mothers' and Fathers' Time with Children comparison of time spent my mothers and fathers.

A. R. (Jan. - Feb., 2002), Parental Involvement: Its Contribution to High School Students' Motivation . The Clearing House, Vol. 75, No. 3 ,pp. 132-134. 
Ismail, Z. (2017). To Study the Difference in the Participation Level of Parents in the Education of Pakistani Students from Grade 7 To 10: Relation with Gender and Level of Studies. Advances in Social Sciences Research Journal, 4(14) 1-10.

Thurston, J. R. ( 1964, Jan), Too Close to Normalcy: Parental Involvement in the Education of Slow Learners. The Clearing House, Vol. 38, No. 5 , pp. 296-298.

Wikelund, K. C. (1989, May), Parent Involvement in Education. Office of Educational Research

Williams, A. R.-D. (Jan. - Feb., 2002), Examining the Underutilization of Parent Involvement in the Schools, the Clearing House. . Vol. 75, No. 3 , pp. 132-134.

Willems, A. R.-D. (2005, June), Parental Involvement:It's Contribution to High School Students Motivation, . Educational Psychology Review, Vol. 17, No. 2,pp. 85-97 